\title{
Quality in the combat: the QFD in support to design of tactics
}

\author{
Emanuel Alexandre Moreira Pessanha, Luís Gonzaga Trabasso \\ Technological Institute of Aeronautics \\ e-mails: correiodopessanha@hotmail.com; gonzaga@ita.br
}

\begin{abstract}
Currently, the international public opinion condemns collateral damages incidents related with warlike activities. In this sense, the present work suggests the use of the Quality Function Deployment (QFD) method in the conception and development of tactics, with the intention to improve quality in the combat by minimizing the damages provoked by wars. To this end, initially, general considerations regarding the development of tactics, QFD and morphological matrix are described, followed by the examination of the proposal under the focus of the productivity frontier. In conclusion, the QFD current application is helpful to improve the tactics involved, equipment selection and to put into practice the perceived procedures to minimize collateral damages, offering better quality to combat actions.
\end{abstract}

Keywords: QFD, product development, tactic.

\section{Introduction}

In the era of knowledge and with the rapid pace of technological change, the design of tactics has become more important. New technologies should be continuously explored and incorporated into military actions.

In armed conflicts, tactical innovations result from the development of technologies and concepts for the battlefield Brasil (2006). For Longo (2007), there seems to be a thread between the demands of the technology industry and military echelons. Operational needs stimulate the progress of equipment, which in turn affects the way of thinking about war Longo (2007). This process can be originated at any point in the chain, as in the existing technological resources Longo (2007).

In the context of the development of tactics, the Protocol I of amendment to the Geneva Conventions prohibits the use of weapons, projectiles and materials that cause unnecessary injury (CONVENÇÃO..., 1977). It also prohibits the adoption of procedures and use of weapons that can cause extensive damage, durable and severe to environment (CONVENÇÃO..., 1977).

The Protocol establishes military operations to spare the civilian population (CONVENÇÃO..., 1977). This forces planners to act cautiously in the choice of means and methods of attack, so as to minimize the collateral damage (CONVENÇÃO..., 1977).

Maltz (1997) points to the adequacy of equipment during combat. For him, this is due to the transition experienced by an armed force, from peacetime to wartime (MALTZ, 1997).

According to Maltz (1977), wars usually end before transformations are completed. Maltz (1997) points out that the adequacy of facilities during combat is an expensive process because it compromises lives and wastes time in the early stages of a conflict.

To provide equipment attuned to the real demands of the war, to meet soldier's demands in advance and reduce rework, Maltz (1977) encourages the use of quality tools. Thus, the present study, when addressing the tactic as a product to be made available to the troops, proposes the application of Quality Function Deployment (QFD), with the goal of providing a high degree of perceived quality to military actions.

The paper is structured as follows: in Section 2, the QFD prepared in support to development of tactics is presented, as well as an example with results, in order to find possible solutions to the issue above. Then, in Section 3 , the proposal is analyzed under the focus of the productivity frontier. Finally complementary analyses and conclusions are described in Section 4.

\section{The proposed QFD}

QFD was developed in Japan during the 1960s. Originally, it had the objectives of assuring quality and aiding in the development process of the new product, so as to translate and forward the needs and desires of the customer since the design phase (CHENG; MELO FILHO, 2007). In the 1980s, the QFD began to be used in Europe and the United States, because of its potential and increased competition on a global scale (CHENG; MELO FILHO, 2007).

According to Cheng and Melo Filho, 2007, the method came to Brazil in the 1990s and currently, in addition to being directed to the initial stage of the life cycle of product 
planning and development, it has also been employed in work on less tangible products such as software and services.

The application of QFD in design and development of tactics required the elaboration of a conceptual model. To this end, it was necessary to involve aspects related to the definition of tactics. To Degen (2008), for example, the tactics depend on the type of plant, equipment, mission, geographical location and other factors.

The field manual of the United States Army, FM 3-0 (DEGEN, 2008), considers that besides to vary with the ground and other circumstances, the tactics change frequently as the enemy reacts and allied forces explore new approaches. As part of the systematic study of a combat situation, the field manual of the Brazilian Army, C 100-5 (BRASIL, 1997), indicates the following factors for decision making: mission, enemy, terrain and weather conditions, means and time.

This work displays tactics as a series of procedures that aims at obtaining the advantage in head-to-head confrontation with an opponent (BRASIL, 2006). Furthermore, it considers that the procedures depend on the factors highlighted in the two preceding paragraphs.

In proposed QFD, the construction of the conceptual model is based on the schemes presented in Figures 1 and 2. In Figure 1, the factors involved in the definition of tactics are related, while in Figure 2, the reverse flow of combat is established.

In Figure 1, with the exception of equipment, the proposal encapsulates all other factors that influence the tactic, according to Degen (2008) in a set called Mission - the broad sense. These factors characterize the Mission in its broadest sense and influence the selection of equipment, the procedures to be adopted and the demands of the world public opinion.

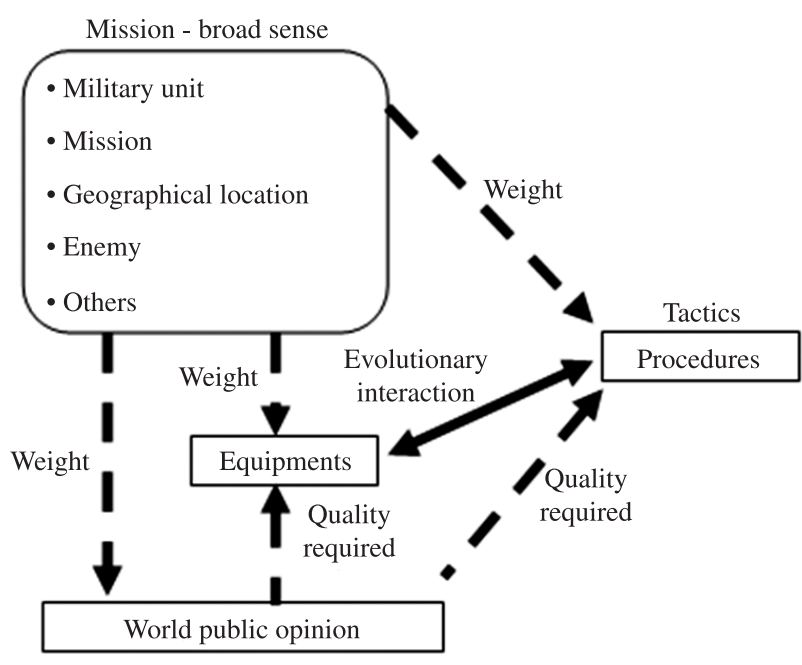

Figure 1. Factors that influence the tactics.
Still in Figure 1, the equipment is treated separately from the mission, as it has a strong relationship with the implementation of the procedures that make up the tactics and consequently with the results obtained. Evolutionary interaction of the procedures and the equipment depicts the dynamic approached by Longo (2007) in this work, which involves operational needs and technologies.

Not made explicit by Degen (2008), public opinion is inserted in Figure 1 as a factor that, in addition to being affected by the mission in the broad sense, exerts influence over the procedures and equipment to be employed in order to provide the required quality.

In accordance with the recommendation of Cheng and Melo Filho (2007), in order to assist the design and development of tactics the QFD was drafted from the opposite direction of the combat flow. In the direction of the combat flow, illustrated in Figure 2, the procedures and equipment once employed (combat), generate results that suffer a greater and more immediate assessment of the public opinion.

Also in Figure 2, now in the opposite direction of the flow, the quality required by the public provides combat requirements during a specified conflict in mission - wide sense (Figure 1). Next, there is the unfolding of the combat requirements in characteristics of the procedures and equipments in order to assist the definition of a set of procedures that comprise the tactics and the equipment to be used. The dashed line on the reverse flow of combat delimits the scope of the conceptual model of the QFD proposed.

The conceptual model presented in Figure 3 lists the characteristics of the equipments and characteristics of its procedures, similar to the reverse combat flow. In it, user requirements are described as qualities required in combat, with the goal of portraying the demands of world public opinion related to military actions. The design requirements are referred to as combat requirements.

Figure 4 depicts the House of Quality used in the proposal in question. Initially, Field I defines the qualities required in combat. Field II presents the quality planning. It consists of the performance evaluation of the target study of this army (the army - today), as well as highlighted armies

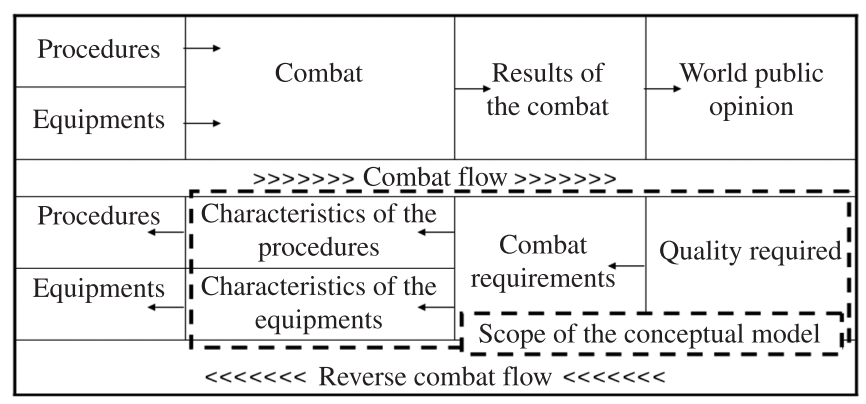

Figure 2. Combat flow. 


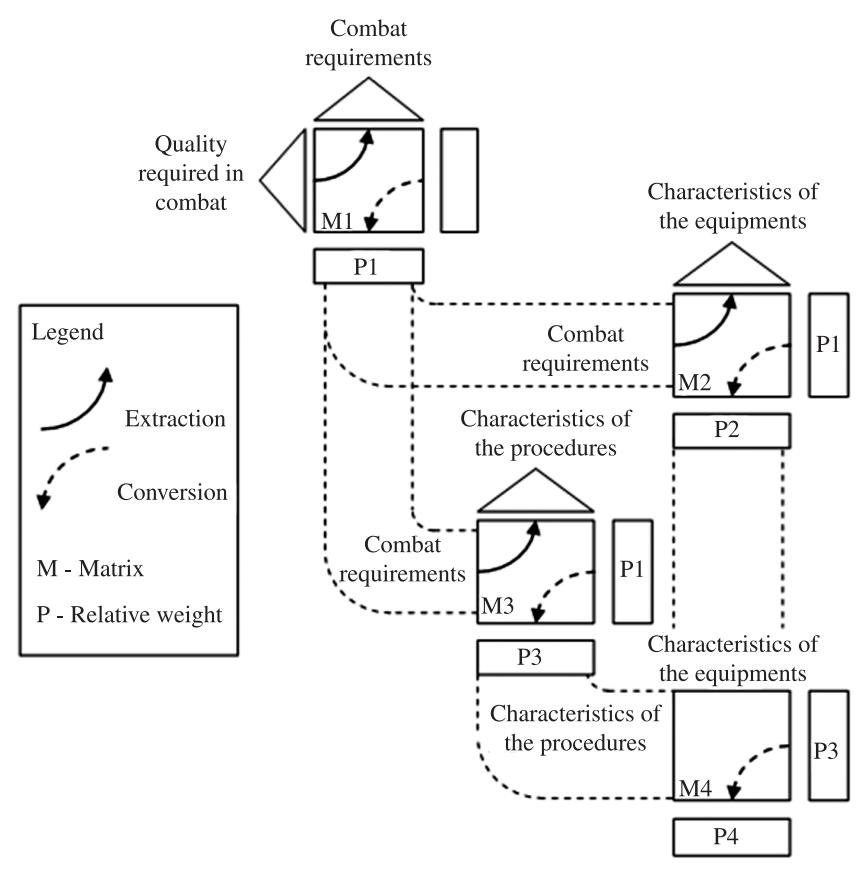

Figure 3. Proposed conceptual model.

in regional and global levels. In the planning topic, planning for quality describes the values relating to the quality plan, argument of professionalism and the improvement index.

The argument of professionalism in Field II of Figure 4, allows an army to concentrate its efforts on obtaining recognition by the international community. The high degree obtained in certain qualities required is a relevant factor in the appointment of an armed force to enforce UN peace missions. Therefore, the argument of professionalism replaces the selling argument in the planning of the quality of a product and is intended to highlight the qualities required in the fight to be perceived internationally as attributes of an army.

After the execution of quality planning, the combat requirements are extracted of the qualities required and recorded in Field III of the House of Quality (CHENG; MELO FILHO, 2007) presented in Figure 4. According to Amaral (2006), the extraction process allows the definition of project requirements (combat requirement) reflecting the product's ability to meet the requirements of the users (qualities).

To Back (2008), the design requirements (combat requirements) play an important role with respect to the satisfaction of users. They establish the parameters, quantities and restrictions, among other product attributes, which allows the mapping of technical problems inherent to a given context.

Following the method are defined intensities of existing relationships in the Field IV of Figure 4, between qualities and combat requirements. In Field IV, the peculiarities of the mission should be taken into consideration, so that the intensities transmit to the QFD the factors intrinsic to the battle.

After the relationship between qualities and combat requirements, the conversion process starts. The conversion process is used to convey the importance of the qualities required for the combat requirements. Therefore, according to Cheng and Melo Filho (2007), the design requirements (combat requirements) are prioritized in accordance with the needs of users (qualities).

The next step, seeks to establish the quality projected. It is recorded in Field VI (Figure 4) and includes the comparison of the design requirements (combat requirements) of the company's current product (the army - today) and competitors (army highlight in global level), as well as the metric used and the goal value of performance established for each project requirement (combat requirements) for the new product (tactics) (BACK et al., 2008).

The information contained in interactions recorded on the roof of the House of Quality (Field V Figure 4) is considered when setting the goal value of performance of each project requirement (requirement of combat) (BACK et al., 2008). The roof of the House of Quality is formed by a matrix that allows analysis of how the changing a project requirement (requirement of combat) influences the behavior of others (CHENG; MELO FILHO, 2007). It allows the identification of conflicting situations (difficult optimization in relation to the quality required), as well as of those interacting positively (ROTONDARO, 2008).

Upon completion of its construction, the House of Quality is unfolded in other arrays, so as to offer greater capacity of detailing to the QFD. The procedures used in different matrices, established by the best-known versions of the QFD, are those made on during the construction of the House of Quality (PEIXOTO, 1998).

In Figure 3, characteristics of the equipments and procedures (from arrays 2 and 3, respectively) are extracted of the combat requirements with larger weights and prioritized. Similarly to the selection of the combat requirements for arrays 2 and 3, characteristics of the equipments and procedures are inherited by the array 4 , from the descending order of their relative weights.

In addition to being present in the House of Quality, the roof was inserted in the arrays 2 (Figure 5) and 3 (Figure 6). In them, it is intended to highlight the characteristics of the equipments and procedures that can be integrated by interacting positively, or balanced by configuring a conflicting situation.

The proposed model makes use of matrix 4, Figure 3, to relate the characteristics of the equipments resulting from matrix 2 (Figure 5) with the characteristics of the procedures from the matrix 3 (Figure 6). In each cell of the matrix 4 (Figure 7), the value assigned is defined by the intensity with which the characteristics of the equipments 


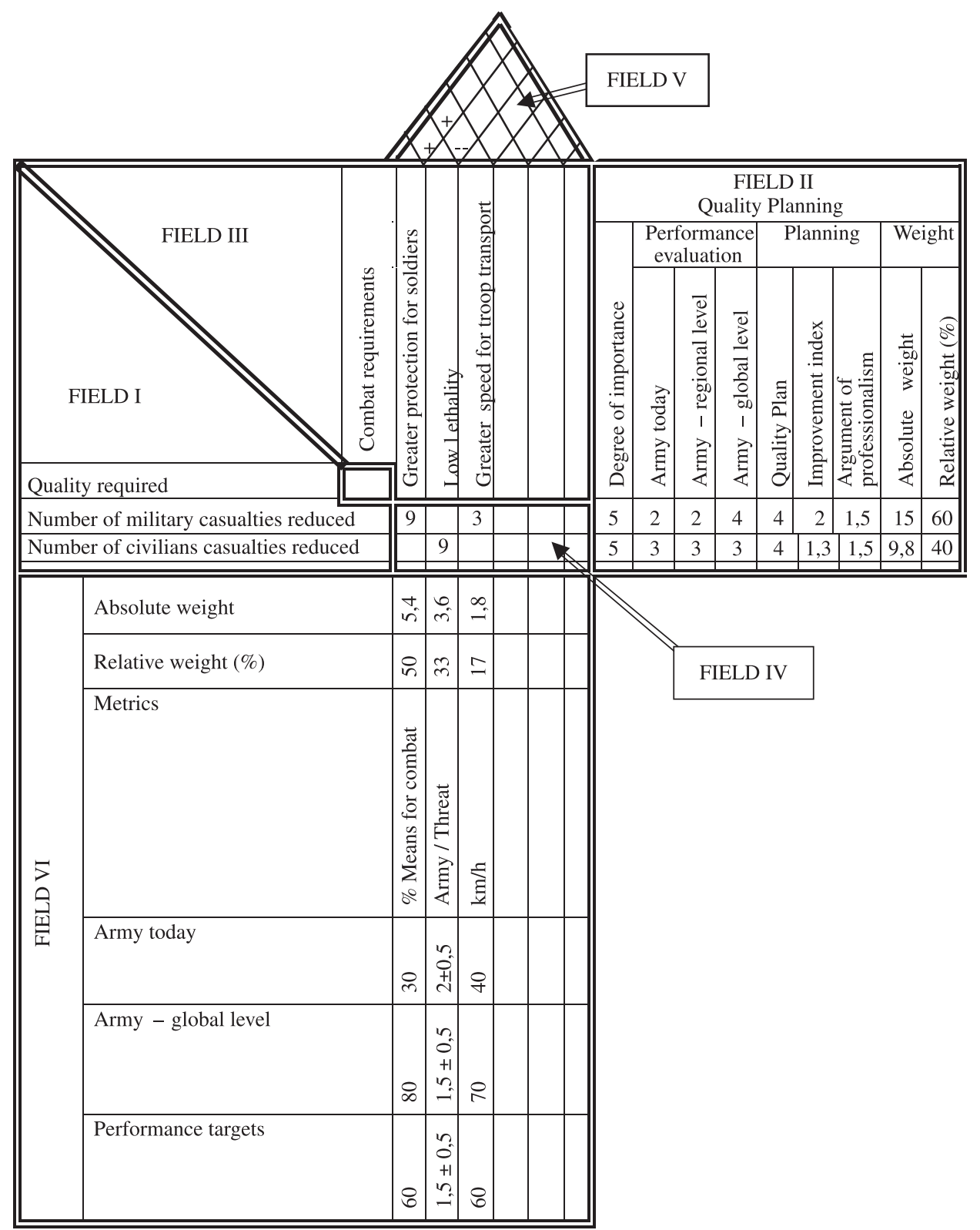

Figure 4. The House of Quality (Matrix 1).

and procedures interact positively as to the possibility of joint implementation.

In the matrix 4 (Figure 7), the absolute weights of the characteristics of procedures are inherited from matrix 3. Matrix 4 prioritizes the characteristics of the equipments related to the relative weights of the characteristics of procedures, the amount and intensity of relationships established. So, it is important to compose the tactics and define the characteristics of the equipments required for its implementation, in order to contribute to the effectiveness of troop training, selection of equipment to be acquired and, consequently, the implementation of financial resources.
The morphological matrix presented in Table 1, next step to the application of the QFD in design and development of combat tactics, is used for generating alternatives. It gathers the characteristics of equipments resulting from array 4 . For each characteristic, alternatives of equipments capable of implementing the tactics are presented.

According to array 4 (Figure 7), characteristics of procedures were incorporated to morphological matrix (Table 1) to highlight the possibilities of employment of each piece of equipment in support to different actions. The morphological matrix provides a visual record of equipment capable of implementing tactics. It offers conditions 


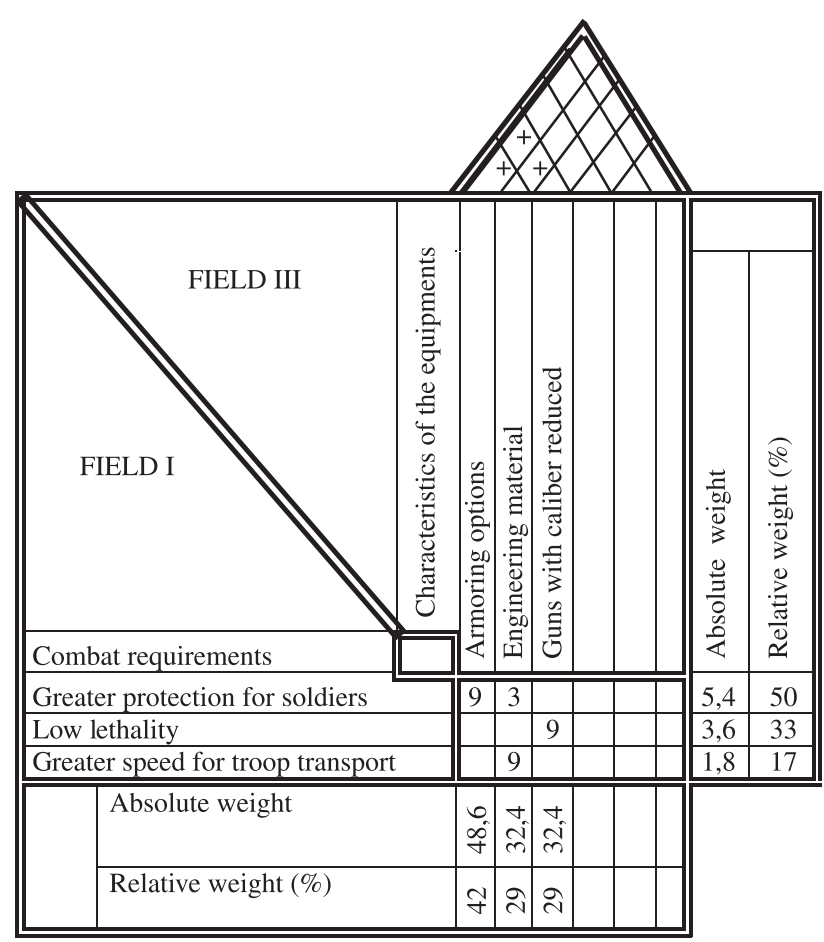

Figure 5. Matrix 2.

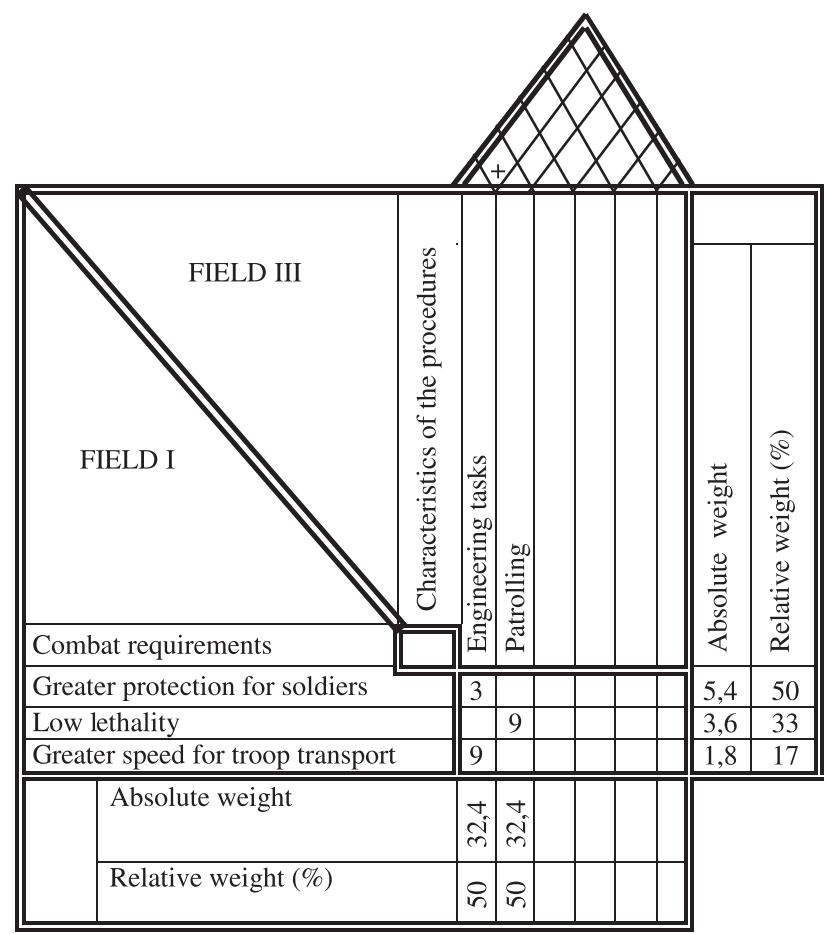

Figure 6. Matrix 3.

favorable to the combination and generation of new means and procedures.

Currently, due to the rapid pace of technological development, the morphological matrix contributes to the tactical innovations, including the insertion of technologies of dual use (civilian and military).

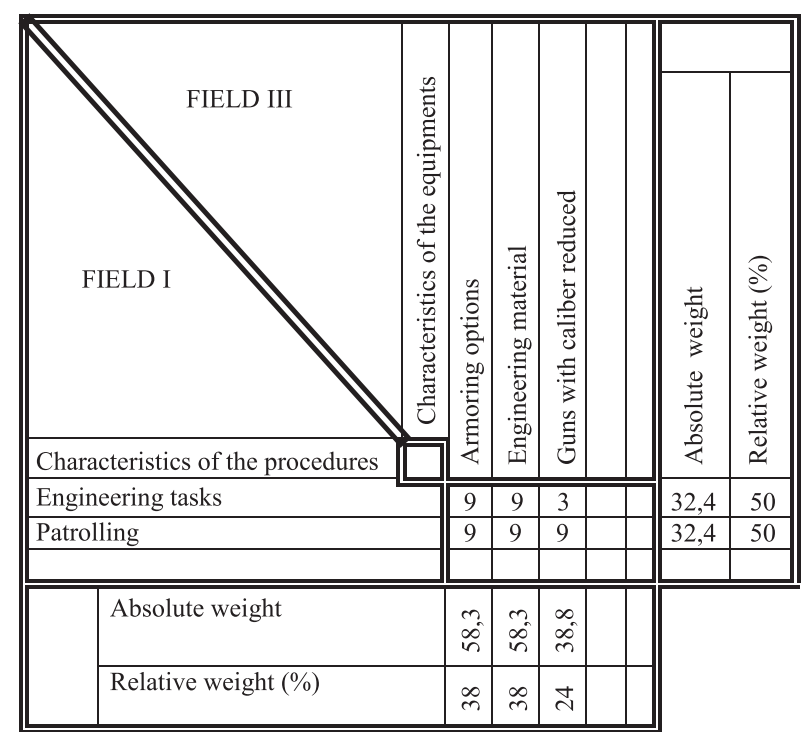

Figure 7. Matrix 4.

Table 1. Morphological array.

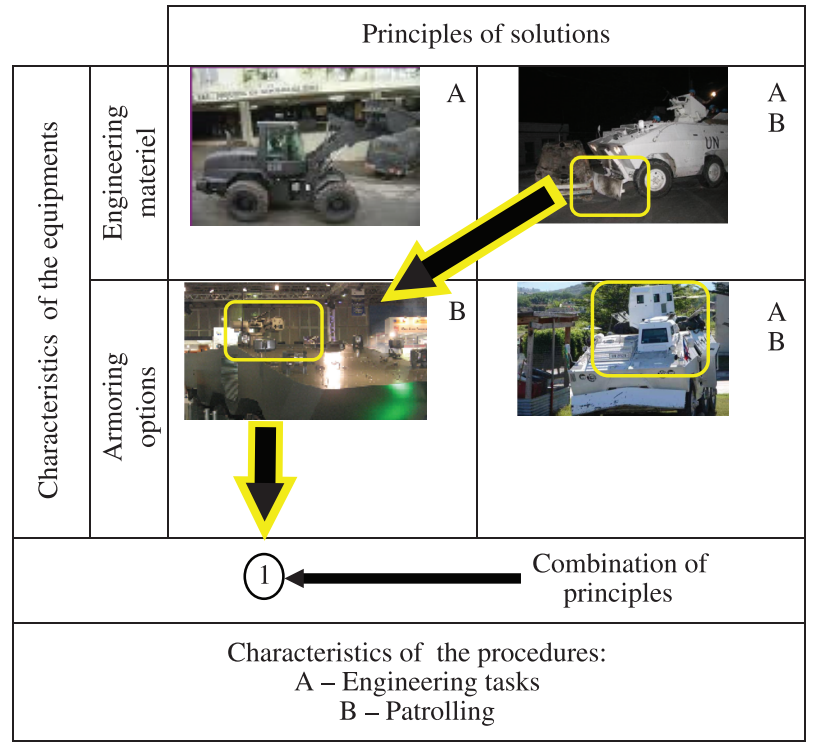

\section{Analysis of the proposal by productivity frontier}

The QFD was used in designing tactics for fighting in urban environment, with the goal of providing improved performance. Its use has facilitated the confirmation of various trends.

For example, the proposal created better conditions to materialize the attention given to reducing the number of casualties of soldiers and civilians in equipment and procedures. Thus, the method has the potential to increase the perceived quality of the equipment and procedures used in urban combat.

The productivity frontier, Figure 8, defines the viable combinations of cost and quality with available technologies 
(DAMIANI, 2009). The productivity frontier is the location of the best practices (DAMIANI, 2009). It provides the highest quality perceived by the customer for a given cost (DAMIANI, 2009).

The method seeks to devise tactics that meet the qualities required in Field I of the House of Quality (Figure 4). Through the generation of alternatives explored in the morphological matrix, it supports the delivery of a product with high perceived quality on the actual demands of the war and in tune with budget realities and technologies available in each country.

The proposal in question seeks to place the development effort on the productivity frontier. The use of the QFD contributes to the anticipation of wartime demands and the consequent reduction of rework in the initial stages of an armed conflict, as suggested by Maltz (1997) in the introduction of the article.

The High Mobility Multipurpose Wheeled Vehicle (HUMVEE) in 2003 in the Iraq war, for example, had a low quality perceived by the combatants. According to Atkinson (2008), after practicing reaction to ambush, soldiers were ordered to place a single layer of sandbags on the floor of the vehicles, shown in Figure 9, to protect them from landmine explosions.

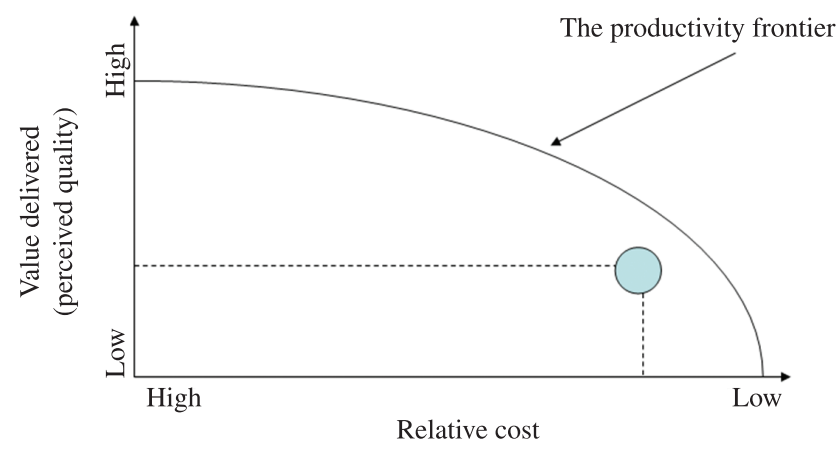

Figure 8. The productivity frontier (DAMIANI, 2009).

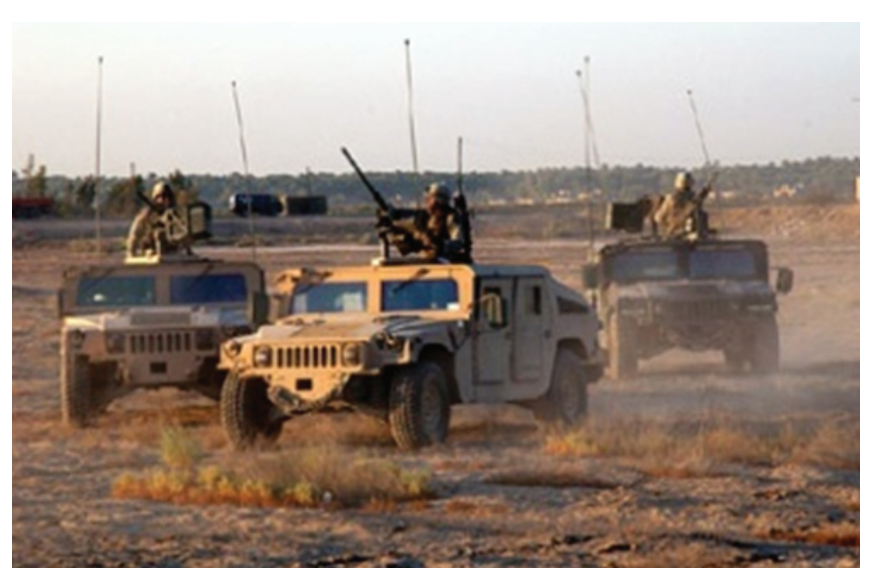

Figure 9. The HUMVEE Vehicle (DOSSIÊ, 2008).
The HUMVEE also aroused the attention of the economist Joseph Eugene (DOSSIÊ, 2008), Nobel Prize for Economics in 2001 and Professor at Columbia University. Eugene says that in 2007, four years after the start of the war and after the death of 1,500 soldiers because of landmines in Iraq, the Pentagon decided to replace the fleet of 18,000 HUMVEE (DOSSIÊ, 2008).

Figure 10 shows the vehicle Mine Resistant Ambush Protected (MRAP) currently used in Iraq and in Afghanistan to replace the HUMVEE (MELLO, 2009). The MRAP differs from HUMVEE because of its greater protection for soldiers from explosions of landmines and improvised explosive devices (IED), due to the amount and thickness of armor (MELLO, 2009).

In Figure 11, the effect of an explosion under the MRAP vehicle and HUMVEE is emphasized. In the MRAP, the deflector shield directs the blast to both sides, away from the crew (BROOK, 2007). In the HUMVEE, the blast is directed towards the crew (BROOK, 2007).

The preference by the MRAP demonstrates that the need for protection from IEDs, in Iraq and in Afghanistan, prevails in relation to the requirement of high mobility offered by the design of the HUMVEE, probably due to the quality required of reduction of the amount of casualties. The choice shows the difficulty of implementing high mobility and armoring options in the same platform.

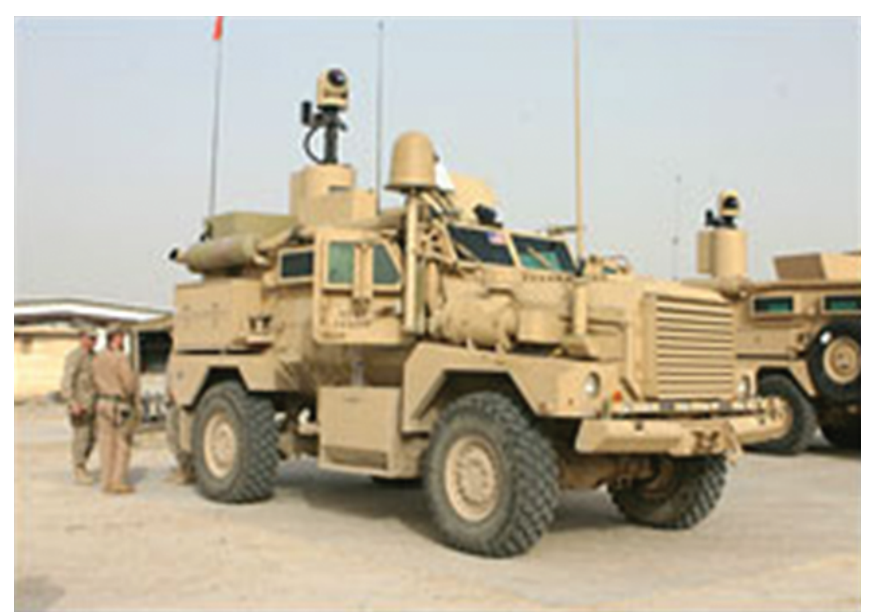

Figure 10. Vehicle MRAP (BEJTLICH, 2007).

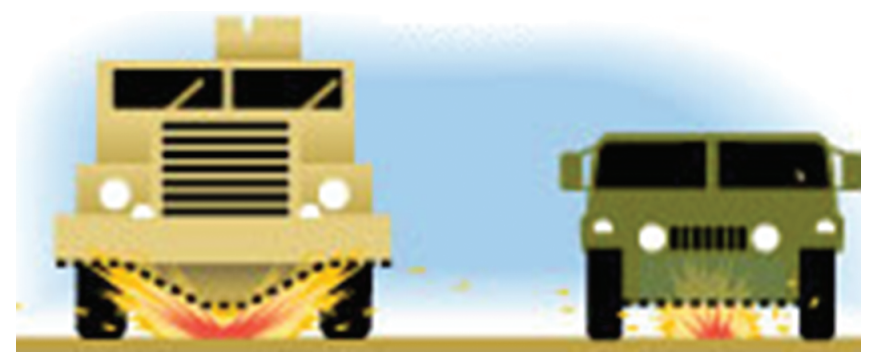

Figure 11. Deflector shield (BROOK, 2007). 


\section{Conclusion}

This work proposes the use of the QFD in quality of combat. Initially, the proposal considerations were presented. Then, the analysis under the focus of the productivity frontier showed that the method can be applied.

The proposed QFD translates the quality required in combat requirements, characteristics of the equipments and procedures, facilitates the traceability of information and provides structured reasoning for the working group. The method allows you to increase the perceived quality of tactics and the identification of trends of development.

The compact and highly visual nature of the QFD matrices, in addition to storing a large amount of data, provides a considerable power of communication, which aids in the accumulation of knowledge on the part of a military organization. The QFD enables a greater integration of participants and promotes a deeper study of the characteristics of the procedures and the equipments.

The use of the method has the potential to strengthen the development of national tactics with high perceived quality. An army can become a world reference on this issue and obtain advantageous position regarding to the conceptual asymmetry.

\section{References}

AMARAL, D. C. et al. Gestão de desenvolvimento de produtos: uma referência para a melhoria do processo. São Paulo: Saraiva, 2006.

ATKINSON, R. Na companhia de soldados: o dia-a-dia da guerra do Iraque. Rio de Janeiro: Bertrand Brasil, 2008.

BACK, N. et al. Projeto integrado de produtos: planejamento, concepção e modelagem. Barueri: Manole, 2008.

BEJTLICH, R. MRAPs lose to arms race. TaoSecurity, 2007. Disponível em: <http://taosecurity.blogspot.com/2007/05/ mraps-lose-to-arms-race.html>. Acesso em: 11 ago. 2009.

BOPE ganha novo equipamento com pá. Rio de Janeiro, 2009. Disponível em: <http://www.sidneyrezende.com/noticia/5 0887+bope+ganha+novo+equipamento+com+pa $>$. Acesso em: 14 maio 2010.

BRASIL. Exército. Arsenal de Guerra de São Paulo adapta Urutu para emprego no Haiti. Brasília: Exército Brasileiro, 2008. Disponível em:<http://www.exercito.gov. br/05notic/paineis/2008/10oublindados.html >. Acesso em: 5 jun. 2009.

BRASIL. Ministério da Defesa. Comando da Aeronáutica. Comando-Geral de Operações Aéreas. NSCA 500-2: Plano estratégico de guerra eletrônica. Brasília: COMGAR, 2006.

BRASIL. Ministério da Defesa. Comando do Exército. C 100-5: Operações. 3. ed. Brasília: EGGCF, 1997. Manual de Campanha.
BROOK, T. V. MRAPs can't stop newest weapon. Washington: GlobalSecurity.org In the News, 2007. Disponível em:<http://www.globalsecurity.org/org/ news/2007/070531-mraps.htm>. Acesso em: 11 ago. 2009.

CHENG, L. C.; MELO FILHO, L. D. R. QFD: desdobramento da função qualidade na gestão de desenvolvimento de produtos. São Paulo: Blucher, 2007.

CONVENÇÃO DE GENEBRA. Protocolo I adicional às convenções de Genebra de 12 de agosto de 1949 relativo à proteção das vítimas dos conflitos armados internacionais. In: CONFERÊNCIA DIPLOMÁTICA SOBRE A REAFIRMAÇÃO E O DESENVOLVIMENTO DO DIREITO INTERNACIONAL HUMANITÁRIO APLICÁVEL AOS CONFLITOS ARMADOS, 1977, Genebra. Disponível em: <http://www.gddc.pt/direitoshumanos/textos-internacionais-dh/tidhuniversais/dih-protI-conv-genebra-12-08-1949.html>. Acesso em: 5 jun. 2009.

DAMIANI, J. H. S. As estratégias empresariais. São José dos Campos: ITA, 2009. Palestra da disciplina MB 238, Gestão Estratégica da Inovação Tecnológica.

DEGEN, E. J. Knowledge Management by the Generating Force. Military Review (Edição em ingles), p. 102-110, 2008. Disponível em: <http://usacac. army.mil/CAC2/MilitaryReview/Archives/English/ MilitaryReview_20080831_art016.pdf>. Acesso em: 30 dez. 2008.

DOSSIÊ - cinco anos da invasão norte-americana ao Iraque: o verdadeiro custo da guerra. Curitiba: Área de Trabalho, 2008. Disponível em: <http://areadetrabalho.wordpress. com/2008/02/28/>. Acesso em: 5 jun. 2009.

KONRAD, K. Urutus no Haiti recebem blindagem especial. Defesa@net, 2006. Disponível em: <http://www.defesanet. com.br/zz/v_cont_30.htm>. Acesso em: 5 jun. 2009.

LONGO, W. P. Tecnologia Militar: conceituação, importância e cerceamento. Tensões Mundiais, v. 3, n. 5, p. 111-143, 2007. Disponível em: <http://www.waldimir.longo.nom.br/ artigos/T9.doc>. Acesso em: 24 mar. 2009.

MALTZ, R. S. Quality leadership as maneuver warfare: a method of instructing and implementing total quality leadership in the Armed Forces. Quality in Warfighting, 1997. Disponível em: <http://www.dau.mil/pubscats/ PubsCats/PM/articles97/maltz.pdf $>$. Acesso em: 11 jun. 2009.

MELLO, P. C. Missão dos EUA enfrenta armadilhas no Afeganistão: em meio a emboscadas em terreno hostil, soldados cortejam aliança com colegas afegãos. O Estado de São Paulo, São Paulo, 26 jun. 2009. Disponível em: $<$ http://www.estadao.com.br/estadaodehoje/20090726/ not_imp408516,0.php>. Acesso em: 12 set. 2009. 
PEIXOTO, M. O. C. Uma proposta de aplicação da metodologia Desdobramento da Função Qualidade (QFD) que sintetiza as versões QFD-estendido e QFD das quatro ênfases. 1998. Dissertação (Mestrado em Engenharia de Produção)-Engenharia de Produção, Universidade de São Paulo, São Carlos, 1998. Disponível em: <http://www.prod.eesc.usp.br/gqm/images/stories/ arquivos/dissertacao_mestrado_manoel_peixoto.pdf $>$. Acesso em: 12 set. 2009.
ROTONDARO, R. G. Seis sigma: estratégia gerencial para a melhoria de processos, produtos e serviços. São Paulo: Atlas, 2008.

SILVA, R. Urutu III terá torre não tripulada. Defesa BR, 2009. Disponível em: <http://defesabr.com/blog/index. php/13/04/2009/urutu-iii-tera-torre-nao-tripulada/>. Acesso em: 5 jun. 2009. 